\title{
Management and Supervision Competences of State Elementary School Principals
}

\author{
N. Gistituati \& H. Suyuthie \\ Universitas Negeri Padang \\ Padang, Indonesia \\ icha_yp@yahoo.com
}

\begin{abstract}
This research investigated the level of management and supervision competencies of State Elementary School Principals at East Padang, West Sumatera regarded from teachers' and principals' responses. This study is quantitative descriptive with total population of 291 teachers and principals of 34 State Elementary Schools. The sample is 137 teachers and 16 principals that were taken by using cluster random sampling technique. The data were collected by using questionnaire and were analyzed by finding out the level of achievement. The findings reveal that according to the teachers, the management and supervision competencies of the principals, in general, are still at the average level; whereas according to principals it is in general, already at the high level. Even though there are different opinions among the principals and teachers, it is undeniable that principals' managerial and supervision competencies, especially in East Padang, need to be amended in order to improve school effectiveness.
\end{abstract}

Keywords—management, supervision, competence

\section{INTRODUCTION}

It cannot be neglected that the success of a school is determined by the principal of the school. As it was stated by Akinola (2013); Hoppey \& McLeskey (2013); Hoy \& Miskel (2013); NASSP \& NAESP (2013); Leithwood \& Levin (2008); Peleg (2012); Piaw et al. (2014); and Yasin (2013) that the principal is the key to the success of the school. The principal is someone who determines and activates all the important components and dimensions of a school. In that position, whether the component of the school is going to be good or not is very much determined by the quality of the principal.

Based on the argumentation above, it can be concluded that whether the school is successful or not is very much depends on the ability of the principal to organize all components of the school. There has been a lot of research indicated that there are relationship between the quality of the principal with the success of the school in accomplishing it's already determined goals, which includes teachers' success in doing their jobs as well as students success in learning (see for example Amuche \& Saleh, 2013; Bouchamma, et.al., 2014; Duze, 2011; Grissom \& Loeb, 2009; Harahap, 2017; Hoppey \& McLeskey, 2013; Leithwood, et.al. 2006; Leithwood \& Jantzi, 2008; Louis, et.al. 2010; and Supovitz et al. 2009). Qualified principals are principals who are able to perform their duties and functions well, who also have knowledge, understanding, and skills about management and leadership as well as other duties that are obliged to them. In Ministerial Regulation of Education No. 13, 2007, the ability of the principal mentioned above is referred to the competences of the principals.

In general, competence is defined as the ability to perform something effectively and efficiently which deals with knowledge, understanding, skills, and attitude (See Bartman, 2007; Kunandar, 2007; Mus-tamin \& Yasin, 2012; Saud, 2009; Wibowo, 2009). From the study of the literature, it was found several differences among scholars in formulating the competences of the leader or principals (see Bhasin, 2012; Hersey et.al. 2008; Hoy \& Miskel, 2013; Pastoriza et.al. 2009; Richter et.al. 2012; and Yukl, 2010). Apart from the differences of the experts in classifying competences, Mumford et.al. (2007) explained that the abilities that principals should have are the abilities in carrying out duties, the ability to solve complex social and technical problems as well as the ability to achieve the already-determined goals effectively and efficiently.

In an attempt to improve the quality of education at schools, Indonesian government through the Ministry of Education had formalized five competencies that should be possessed by principals at any level of schooling, namely: (1) management competence; (2) personal competence; (3) social competence; (4) supervision competence; and (5) entrepreneurship competence (Ministerial Regulation of Education No 13, 2007). Apart from formulating the five competencies above that should be possessed by the principals, the Ministry of Education also issued the regulation where the candidates for principal must already possess Principals Certificate as the result of their competence test, which is stated in Ministerial Regulation of Education No 28, 2010 .

The two regulations mentioned above are very important to be implemented in order to improve the quality of education at schools. As a matter of fact, there are many heads of district (Mayors or Regents) who are not implementing those regulations in selecting and appointing principals for example in West Sumatera. It was not a secret and generally happened that most of the Mayors or Regents in West Sumatera select and appoint school principals based more on the personal purposes. 
Based on the explanation above, it seems necessary to quality of education at schools, especially management and supervision competencies.

\section{METHOD}

This study is a descriptive quantitative with the population about 291 teachers and principals that spread in 34 schools in East Padang. The sample is 137 teachers and 16 principals (defined by using Qohran formula) were taken by using cluster random sampling technique. Instruments used to collect data are questioners with Likert scale model which have five alternative answers related to the degree of knowledge, understanding, skills, and attitude that the principals have on management and supervision which is measured based on the opinion of the teachers and principals. For management competence, the questioner was developed by connecting the dimension of management competence of principals which are formulated in the Ministerial Regulation of Education No. 13, 2007 with the managerial aspects of schools, and finally, there (see Table 1). The final version of the questionnaire of management competence of principal consists of 87 items.

For supervision competence, the questioner was developed in three dimensions of supervision, namely: planning, conducting and evaluating supervision activity (Ministerial are 12 dimensions of management competence of principal

measure principal competencies as an effort to improve the Regulation of Education No 13, 2007). The final version of the questionnaire of supervision competence of principal consists of 40 items. Collected data were analyzed by finding out the mean score (MS) and achievement level (AL); and the criteria to interpret the findings are: $90 \%-100 \%$ (Very High); 80\%-89\% (High); 66\%-79\% (Average); 55\%-65\% (Under Average); and $\leq 54 \%$ (Low).

\section{RESUlTS AND DISCUSSION}

\section{A. Research Findings}

There are two main research questions to be answered in this study, they are: (1) how high is the management competence of elementary school principals in East Padang according to the teachers' and principals' opinion; and (2) how high is the supervision competence of elementary school principals in East Padang according to the teachers and principals' opinion. The data is displayed below. Finally, complete content and organizational editing before formatting.

\section{1) Managerial Competence of the Principals in East Padang}

As already been mentioned above, there are 12 dimensions of management competence of the principals measured in this study. The result of the data analyzed can be seen in Table 1.

\begin{tabular}{|c|c|c|c|c|c|c|c|}
\hline \multirow[t]{2}{*}{ No } & \multirow{2}{*}{ Managerial Competence of Principals } & \multicolumn{3}{|c|}{ Teachers' Responses } & \multicolumn{3}{|c|}{ Principals' Responses } \\
\hline & & MS & $\mathrm{AL}(\%)$ & Category & MS & $\mathrm{AL}(\%)$ & Category \\
\hline 1 & Planning and organizing & 3.93 & 78,65 & Average & 3.92 & 78.33 & Average \\
\hline 2 & Managing curriculum and learning process & 3.88 & 74,92 & Average & 3.94 & 78.76 & Average \\
\hline 3 & Managing students affair & 4,00 & 80,00 & High & 4.12 & 82,50 & High \\
\hline 4 & Managing facilities & 4,05 & 81.00 & High & 4.16 & 83,13 & High \\
\hline 5 & Managing human resources & 4.06 & 81,16 & High & 4.17 & 83,41 & High \\
\hline 6 & Managing finance & 4,00 & 80,00 & High & 4.14 & 82.80 & High \\
\hline 7 & Managing public relations & 3.73 & 74.60 & Average & 4.10 & 82.00 & High \\
\hline 8 & Managing office & 4.03 & 80,60 & High & 4.16 & 83,13 & High \\
\hline 9 & Managing information system & 3.44 & 68,76 & Average & 3,65 & 73,00 & Average \\
\hline 10 & Monitoring and evaluation & 3.72 & 74.42 & Average & 4.16 & 83,13 & High \\
\hline 11 & Leading the school & 3.68 & 73.62 & Average & 4,19 & 83,75 & High \\
\hline \multirow[t]{3}{*}{12} & Managing academic supporting services & 3.53 & 70,66 & Average & 3,75 & 75,00 & Average \\
\hline & Total Mean & 3.83 & 76.53 & Average & 4.04 & 80.76 & High \\
\hline & Opinion of both teachers and principals & \multicolumn{6}{|c|}{$\mathrm{MS}=3.93 ; \mathrm{AL}=78.65 \% ;$ Category "Average" } \\
\hline
\end{tabular}

Table 1 shows that there is a different opinion between teachers and principals concerning to management competence of the principals. According to the teachers, the management competence of the principals, in general, is still at the average level, with the mean score (MS) of 3.83 and the achievement level (AL) of $76.53 \%$; whereas according to principals, their management competence, in general, is already at the high level with MS of $4.04 \%$ and AL of $80.76 \%$. However, when the result closely analyzed, there are several competence dimensions where teachers and principals

\begin{tabular}{|c|c|c|c|c|c|c|c|}
\hline \multirow[t]{2}{*}{ No } & \multirow[t]{2}{*}{ Supervision Competence } & \multicolumn{3}{|c|}{ Teachers' responses } & \multicolumn{3}{|c|}{ Principals' responses } \\
\hline & & MS & $\mathrm{AL}(\%)$ & Category & MS & $\mathrm{AL}(\%)$ & Category \\
\hline 1 & $\begin{array}{l}\text { Planning supervision program } \\
\text { - Ability to identify teachers' need } \\
\text { - Understanding the concept of supervision } \\
\text { - Understanding supervision techniques } \\
\text { - Understanding supervision approaches } \\
\text { - Planning supervision activities } \\
\text { - Giving understanding to teachers about the importance of } \\
\text { supervision activities }\end{array}$ & $\begin{array}{l}3.91 \\
4.07 \\
4.13 \\
3.42 \\
3.89 \\
4.03 \\
3.70\end{array}$ & $\begin{array}{l}78.20 \\
81.46 \\
82.52 \\
68.32 \\
77.96 \\
80.58 \\
74.01\end{array}$ & Average & $\begin{array}{l}4.06 \\
4.06 \\
4.19 \\
3.94 \\
3.87 \\
4.00 \\
4.19\end{array}$ & $\begin{array}{l}81,25 \\
81.25 \\
83.75 \\
78.75 \\
77.50 \\
80.00 \\
83.75\end{array}$ & High \\
\hline
\end{tabular}

have income where both of them have graded high or low level of achievement (see Table 1).

\section{2) Supervision Competence of Principals in East Padang}

There are three aspects measured related to the supervision competence of principals, they are competence related to (1) planning supervision; (2) conducting supervision; and (3) evaluating supervision program. The findings are described in Table 2. 


\begin{tabular}{|c|c|c|c|c|c|c|c|}
\hline 2 & $\begin{array}{l}\text { Conducting supervision activities } \\
\text { - Conducting effective class visit } \\
\text { - Using supervision approaches } \\
\text { - Using supervision techniques } \\
\text { - Developing teachers pedagogical competence } \\
\text { - Developing teachers professional competence } \\
\text { - Developing teachers social and personal competence }\end{array}$ & $\begin{array}{l}3.90 \\
3.61 \\
3.89 \\
3.91 \\
3.93 \\
3.96 \\
4.12\end{array}$ & $\begin{array}{l}78.07 \\
72.27 \\
77.96 \\
78.20 \\
78.54 \\
79.18 \\
82.50\end{array}$ & Average & $\begin{array}{l}4.12 \\
4.08 \\
3.87 \\
4.12 \\
4.12 \\
4.13 \\
4.44 \\
\end{array}$ & $\begin{array}{l}82.53 \\
81.67 \\
77.40 \\
82.50 \\
82.33 \\
82.52 \\
88.80\end{array}$ & High \\
\hline 3 & $\begin{array}{l}\text { Evaluating supervision program } \\
\text { - Conducting evaluation of supervision program } \\
\text { - Using the result of evaluation of supervision program } \\
\text { - Giving feedback on the result of supervision }\end{array}$ & $\begin{array}{c}3.88 \\
4.04 \\
4.01 \\
3.62\end{array}$ & $\begin{array}{l}77.86 \\
80.88 \\
80.29 \\
72.41\end{array}$ & Average & $\begin{array}{c}4.04 \\
4.06 \\
4.06 \\
4.00\end{array}$ & $\begin{array}{l}80.83 \\
81.25 \\
81.25 \\
80.00\end{array}$ & High \\
\hline & Total Mean & 3.89 & 78.04 & Average & 4.07 & 81.53 & High \\
\hline & Opinion of both teachers and principals & \multicolumn{6}{|c|}{$\mathrm{MS}=3.98 ; \mathrm{AL}=79.60 \% ;$ Category $=$ Average } \\
\hline
\end{tabular}

Table 2 shows that there is a different opinion between teachers and principals concerning to supervision competence of the principals. According to teachers, the supervision competence of the principals, in general, is still at the average level, with the mean score (MS) of $3.89 \%$ and the achievement level (AL) of $78.04 \%$; whereas according to principals, their supervision competence, in general, is already at the high level with MS of $4.07 \%$ and AL of $81.53 \%$.

\section{B. Discussion}

\section{1) Managerial and Supervision Competencies of Principals in East Padang}

The result indicated that in general, management and supervision competencies of principals in East Padang according to teachers are still at the "average" level; but, according to the principals, their management and supervision competencies are already at the "high" level. At a glance, it can be seen that there are differences between the score given by teachers and principals related to the management and supervision competencies of principals. However, when it is analyzed closely, the differences that are shown are not too significant. Although teachers' assumption is on the level of "average", the score almost reach the level of "high". So is the score from the principals, although the score is in the level of "high", the score almost close to the level "average".

The different opinion between teachers and principals about principals' managerial and supervision competencies is not too surprising since this activity involved subjectivity aspect. Nevertheless, apart from differences of score given by teachers and principals, the managerial and supervision competencies of primary school principals in East Padang need to be improved. It is also related to the fact that the effectiveness of learning activities in this area has not really satisfied yet (see the result of National Examination 2016).

It was mentioned that having high management competence is very important for a principal in order to be able to manage all school components, especially in adjusting all school activities with the demand of globalization, society changes, development of science and technology, curriculum changes as well as the demand of the situation and condition of the environment. Moreover, having good supervision competence will make a principal able to help teachers to improve their professionalism, so the teachers will be able to perform their duties in professional ways and at the end, students learning outcome will improve. As Glickman et.al (2010) said that supervision is a process of helping teachers to improve their professional competence so the student's achievement can be improved.

The fact that the elementary school principals still lack of management and supervision competencies, especially according to teachers, can be caused by several factors. One of the factors is the recruitment process for the candidates of principal. It was not being processed in selective ways. In Indonesian system of government, the principals are selected and appointed by the Mayor (Wali Kota) or the Regent (Bupati). Most of the Mayors or the Regents in Indonesia, especially in West Sumatera, select and appoint the principals without preferring on the candidates' competence in managing the school as it has been stated in the Ministerial Regulation of Education No. 13, 2007 related to the competencies that the principals should have. The process of selection did not follow the process as it is stated in the Ministerial Regulation of Education No. 28, 2010 related to the requirements and recruitment system of principals' appointment. The Mayors or the Regents are more likely to select and appoint the principal based only for their personal purposes. They were mostly select the principal candidates based on the contribution that the candidates have made for the winning of the Mayors or the Regents in their election process. In other words, the recruitment and the selection process of the principal candidates have been politicized by the Mayors or the Regents. For the effectiveness of the schools, the recruitment and the selection process of the principal candidates should actually be more selective by selecting candidates with good managerial and supervision competencies as it was required by the Ministerial Regulation of education No. 13, 2007; and the process of selection itself should really follow the Ministerial Regulation of Education No. 28, 2010.

Moreover, the lack of management and supervision competencies of the principals can also be caused by the limited amount of training that principals have to upgrade their management and supervision competencies (from the interview with several primary school principals in Padang). As it is known that the management and supervision competencies of the principals should continuously be improved accordingly to the advancement of science and technology, including science and technology related to education. In fact, the research found that according to both principals and teachers, the primary school principals in East Padang still lack of competence in managing technological information system; curriculum and learning process, especially learning process using technological information; helping teachers in improving their pedagogic and professional competences. 
Considering the importance of management and supervision competencies of the principals for school effectiveness; thus, management and supervision competencies of the principals should be take into account a serious attention by the government.

\section{CONCLUSION}

Based on the research findings and discussion, it can be concluded that in general, the management and supervision competencies of the primary school principals in East Padang are inadequate, even though the principals already gave a score on the level of "high". In fact, judging from the mean score of the achievement of both teachers and principals, it is in general still at the level of "average". Considering the importance of management and supervision competencies for principals in improving the quality of school; therefore, it is necessary for the Mayors or the Regents, especially in West Sumatera, to put their serious attention concerning to management and supervision competencies of their primary school principals.

Managerial competence that need special attention to be improved soon are in term of managing information system, managing academic supporting services such as libraries, health center, and counseling unit; managing curriculum and learning process; and planning and organizing. Supervision competence that should be improved immediately is in case of mastery of techniques and approach of supervision, conducting effective classroom visit, helping teachers to develop their pedagogic and professional competence and giving feedback on the result of supervision activity.

\section{References}

[1] Akinola, O. B.2013. Principals' leadership skills and school effectiveness: The case of South Western Nigeria. World Journal of Education, 3(5), 26-33.

[2] Amuche, C. I., and Saleh, D.A.2013. Principals managerial competence as a correlate of students' academic performance in Ecwa Secondary Schools in North Central Nigeria. Journal of Education and Practice 4(4): $247-256$

[3] Bartman, L.K.J, Bastiaens, T.J, Kirschner, P.A., \& Van Der Vleuten, C.P.M. 2007. Evaluating assessment quality incompetence two frameworks. Educational Research Review 2: 114-129.

[4] Bhasin, M. L.2012. Measurement and disclosure of intellectual capital in a developing country: An exploratory study. Australian Journal of Business and Management Research, 52(8), 63-75.

[5] Bouchamma, Y., Basque, M., \& Marcottelet, C.2014. School management competencies: Perceptions and self-efficacy beliefs of school principals. Creative Education 5: 580-589. Retrieved 15 May 2017 from http://dx.doi.org/10.4236/ce.2014.58069.

[6] Duze, C. O. 2011. Falling standards of education in Nigeria: An empirical evidence in Delta State of Nigeria. Lwati: A Journal of Contemporary Research, 8(3), 1-12.

[7] Glickman, C.D., Gordon, S.P., \& Ross-Gordon, J.M. 2010. Supervision and instructional leadership: A developmental approach, 8th ed. New York: Allyn \& Bacon

[8] Grissom, J.A. \& Loeb, S. 2009. Triangulating principal effectiveness: How perspectives of parents, teachers, and assistant principals identify the central importance of managerial skills. IRePP Stanford University: School Leadership Research Paper.

[9] Harahap, F. 2017. The influence of principal managerial competency toward teachers' productivity and organizational citizenship behavior (OCB) by mediation of interpersonal communication of State Vocational High School South Tapanuli, North Sumatera. OSR Journal Of Humanities And Social Science (IOSR-JHSS) 22(1): 2279-0845. Retrieved on 15 May from www.iosrjournals.org

[10] Hersey, P., Blanchard, K.H., \& Johnson, D.E. 2008. Management of organizational behavior, 9 th ed. NJ: Prentice Hall.

[11] Hoppey, D., \& McLeskey, J. 2013. A case study of principal leadership in an effective inclusive school. The Journal of Special Education, 46(4), 245-256.

[12] Hoy, W.K. \& Miskel, C.G. 2013. Educational administration: Theory, research, and practice, 9 th.ed. Singapore: McGraw Hill.

[13] Kunandar. 2007. Guru profesional. Jakarta: PT. Rajagrafindo Persada.

[14] Leithwood, K., Day, C., Sammons, P., Harris, A., \& Hopkins, D. 2006. Seven strong claims about successful school leadership. Nottingham: NCSL/DFES Publications.

[15] Leithwood, K., \& Jantzi, D. 2008. Linking leadership to student learning: The contributions of leader efficacy. Educational Administration Quarterly, 44(4), 496-528.

[16] Leithwood, K. \& Levin, B. 2008. Understanding and assessing the impact of leadership development. In J. Lumby, G. Y. Bouchamma, \& P. Pashiardis (Eds.), International Handbook on the Preparation and Development of School Leaders: 280- 302. New York: Taylor and Francis.

[17] Louis, K. S., Leithwood, K., Wahlstrom, K., \& Anderson, S. 2010 Investigating the links to improved student learning: Final report of research findings. New York: Wallace Foundation.

[18] Mumford, T. V., Campion, M. A., \& Morgeson, F. P. 2007. The leadership skills strataplex: Leadership skill requirements across organizational levels. The Leadership Quarterly, 18(2), 154-166.

[19] Mustamin \& Yasin, M.A. 2012. The competence of school principals: What kind of need competence for school success? Journal of Education and Learning 6(1): 33-42.

[20] Pastoriza, D., Ariño, M. A., \& Ricart, J. E. 2009. Creating an ethical work context: A pathway to generate social capital in the firm. Journal of Business ethics, 88(3), 477-489.

[21] Peleg, S. 2012. The role of leadership in the education system. Education Journal, 1(1), 5-8.

[22] Piaw, C. Y., Hee, T. F., Ismail, N. R., \& Ying, L. H. 2014. Factors of leadership skills of secondary school principals. Procedia-Social and Behavioral Sciences, 116, 5125-5129.

[23] Richter, M. M., Lewis, T. J., \& Hagar, J. 2012. The relationship between principal leadership skills and school-wide positive behavior support: An exploratory study. Journal of Positive Behavior Interventions, 14(2), 69-77.

[24] Saud, Udin Syaefudin. 2009. Pengembangan Profesi Guru. Bandung: Alfabeta.

[25] Supovitz, J., Sirinides, P., \& May, H.2009. How principals and peers influence teaching and learning. Educational Administration Quarterly, 46(1), 31-56.

[26] Wibowo. 2009. Managemen kinerja. Jakarta: Rajawali Press.

[27] Yukl, G.A. 2010. Leadership in organizations, 7th ed. Upper Saddle River, NJ: Prentice Hall

[28] Yasin, M.A., Mustamin, \& Tahir, L.M. 2013. Principal competencies and the achievement of national education standard in Indonesia. International Online Journal of Humanities and Social Science Invention 2(8): pp.31-36. 